\title{
Effectiveness of complementary therapies for the management of symptom clusters in palliative care in pediatric oncology: a systematic review
}

Efetividade de terapias complementares para o manejo de clusters de sintomas em cuidados paliativos em oncopediatria: revisão sistemática

Efectividad de las terapias complementarias para el manejo de los grupos de síntomas en los cuidados paliativos en oncopediatría: revisión sistemática

How to cite this article:

Lopes-Júnior LC, Urbano IR, Schuab SIPC, Pessanha RM, Rosa GS, Lima RAG. Effectiveness of complementary therapies for the management of symptom clusters in palliative care in pediatric oncology: a systematic review. Rev Esc Enferm USP. 2021;55:e03709. doi: https://doi.org/10.1590/S1980220X2020025103709

Luís Carlos Lopes-Júnior ${ }^{1}$

Isadora Rangel Urbano ${ }^{1}$

Sara Isabel Pimentel de Carvalho Schuab ${ }^{1}$

Raphael Manhães Pessanha ${ }^{1}$

Gabriela Sylvestre Rosa ${ }^{1}$

Regina Aparecida Garcia de Lima ${ }^{2}$

1 Universidade Federal do Espírito Santo, Centro de Ciências da Saúde, Departamento de Enfermagem, Vitória, ES, Brazil.

${ }^{2}$ Universidade de São Paulo, Escola de Enfermagem de Ribeirão Preto, Departamento de Enfermagem Materno Infantil e Saúde Pública, Ribeirão Preto, SP, Brazil.

\begin{abstract}
Objective: To evaluate the effectiveness of complementary therapies in the management of symptom clusters in children and adolescents with cancer undergoing palliative care. Method: Systematic review guided by the Preferred Reporting Items for Systematic Reviews and Meta-Analyses, resorting to the databases MEDLINE, Web of Science, Central Cochrane, and PsycINFO. The identification, selection, inclusion, extraction, and methodological assessment were conducted by two independent reviewers. Results: Five quasi-experiments met the eligibility criteria. The heterogeneous characteristics of the studies made meta-analysis impossible. Two studies used therapeutic massage, one used Reiki, one used boswellic acid, and one used Cannabis sativa; three of them (therapeutic massage and Reiki) presented statistically significant results for the management of the cluster pain-anxiety-worry-dyspnea. Most studies presented a moderate risk of bias as per ROBINS-I tool. Conclusion: Therapeutic massage and Reiki may be effective for the symptom clusters management, especially the pain-anxiety-worry-dyspnea cluster in children and adolescents undergoing palliative care.
\end{abstract}

\section{DESCRIPTORS}

Child; Adolescent; Palliative Care; Complementary Therapies; Oncology Nursing; Review. 


\section{INTRODUCTION}

Rising to alarming levels, cancer is a contemporary worldwide public health problem and the second cause of mortality in several countries ${ }^{(1)}$. Particularly, cancer in children and adolescents (from 0 to 19 years old) corresponds to a group of many diseases that have in common the uncontrolled proliferation of abnormal cells and may occur in any part of the organism ${ }^{(2)}$. The global incidence of childhood cancer is increasing ${ }^{(3)}$. Estimates suggest 300 thousand new cases among children and adolescents up to 19 years old worldwide $^{(4)}$. Pediatric tumors correspond to 1 to $4 \%$ of all malignant tumors in most populations ${ }^{(2)}$. In developing countries, where the population of children amounts to around $50 \%$, this proportion corresponds to 3 to $10 \%$ of all neoplasms ${ }^{(3)}$. In Brazil, from 2020 to 2022, 4,310 new cases of cancer in children and teenagers are estimated for males, and 4,150 for females ${ }^{(5)}$.

Despite the progress in the diagnostic and therapeutic process in pediatric oncology, as well as the increase in survival for children and adolescents with cancer, part of these patients is not cured and benefit from palliative care as a fundamental focus of healthcare ${ }^{(6-8)}$. The objective of palliative care in children and adolescents is improving their quality of life, as well as of their families when they face lifelimiting or deadly diseases. According to the World Health Organization (WHO), palliative care for this population comprises total active care of body, mind, and spirit, as well as providing family support ${ }^{(9)}$, which should start when the disease is diagnosed and continue regardless of treatment directed at the disease ${ }^{(10-11)}$.

When in its advanced form, cancer in children and adolescents evolves with the presence of symptom clusters which are hardly controllable and manageable, such as pain, nausea, vomit, anorexia, fatigue, depression, anxiety, and others ${ }^{(12-14)}$. The term cluster is defined as a group of symptoms which are related to one another and may be predicted ${ }^{(15)}$. A cluster of neuropsychological symptoms is defined as two or more emotional, behavioral, and physical symptoms which occur simultaneously and interrelatedly. The symptoms of a cluster have stronger relations with one another than with symptoms outside the cluster ${ }^{(15-16)}$. A cluster of neuropsychological symptoms was observed for the first time in laboratory animals submitted to induced infectious conditions (induced by gram-negative bacterial wall LPS - lipopolysaccharide) and the inoculation of pro-inflammatory cytokines. The result of these infectious and inflammatory conditions was a phenomenon known as sickness behavior ${ }^{(16)}$. The manifestations of sickness behavior may be related to tumor invasion, as well as adverse effects of treatment of some types of cancer, causing an intense discomfort to the patients and reducing their functional state, with a consequent reduction in quality of life ${ }^{(17-18)}$. Due to the high prevalence of cancer symptom clusters in palliative care in pediatric oncology, their management is crucial in pediatric oncology and one of the essential pillars of Nursing in Oncology ${ }^{(16,18-19)}$. Patients with cancer undergoing palliative care may benefit from the use of
Complementary Therapies (CT), as a support to treatment, mainly for the management of cancer symptom clusters $^{(20-22)}$.

The National Center for Complementary and Alternative Medicine (NCCAM) defines Complementary Alternative Medicine as a set of practices, medical and healthcare systems which are not considered part of conventional medicine ${ }^{(23)}$. The $\mathrm{CT}$ include techniques which aim at prevention, promotion, treatment, and recovery, to integrate the physical, mental, and spiritual dimensions of human beings ${ }^{(24)}$. There are many forms of classifying these therapies. The NCCAM classifies them mainly as use of natural products, practices of body and mind, and manipulation practices based on the body ${ }^{(23)}$.

Although there is robust scientific evidence of the effectiveness of the use of complementary therapies used for the management of specific symptoms in children and adolescents with cancer ${ }^{(7,25-30)}$, there is still a gap in the literature related to the effectiveness of complementary therapies in the management of symptom clusters, particularly in children and adolescents with cancer undergoing palliative care. Also, a search for registers of titles and protocols, as well as articles of systematic reviews, was carried out; however, no results were found regarding this specific theme. In this sense, the objective of this study was to evaluate the effectiveness of complementary therapies in the management of symptoms clusters in children and adolescents with cancer undergoing palliative care.

\section{METHOD}

\section{DESIGN OF STUdY}

This study is a systematic review which included writing a report following the Preferred Reporting Items for Systematic Reviews and Meta-Analyses (PRISMA) ${ }^{(31)}$. A protocol in the International Prospective Register of Systematic Reviews (PROSPERO/NHS) - Registry Number: CRD42020167468 was registered to guarantee the reliability of data and methodological transparency.

To formulate the objective and the research question for the review the strategy $\mathrm{PICO}^{(32)}(\mathrm{P}-$ Population or Patients; I Intervention; $\mathrm{C}$ - Comparison; $\mathrm{O}$ - Outcomes) was employed, where $\mathrm{P}=$ Population (children and adolescents with cancer undergoing palliative care), I = Intervention (complementary therapies), $\mathrm{C}=$ Comparison (control group receiving no intervention or receiving standard/usual clinical care), $\mathrm{O}=$ Outcomes (improvement in cancer symptom clusters).

The definition of palliative care of the $\mathrm{WHO}$ was used in this systematic review to compose the element $\mathrm{P}$ (population in the PICO strategy) which determines palliative care as being an approach which enhances quality of life of patients and of families who face problems associated to diseases through prevention and suffering relief, early identification, correct evaluation, and pain treatment and of other problems of a physical, psychosocial, and spiritual nature ${ }^{(9)}$. The term cluster is defined as a set of symptoms related to one another and which may be predicted ${ }^{(15)}$. Such definitions and elements of the PICO strategy have facilitated the elaboration of the critical thinking on the theme and the formulation of the guiding question of this review: "What are the scientific evidence of the effectiveness of complementary therapies 
in the management of cancer symptom clusters in children and adolescents with cancer undergoing palliative care"?

\section{Search Strategy}

The systematic search for primary studies was conducted in four electronic databases: MEDLINE - Medical Literature Analysis and Retrieval System Online (via PubMed), Cochrane Central Register of Controlled Trials (CENTRAL Cochrane), Web of Science, and PsycINFO (Psychology Information). The search strategy for these studies included a combination of controlled descriptors (indexing terms in each database) and keywords, following the indication offered in each electronic database. Thus, to search articles in MEDLINE, Medical Subject Headings (MeSH) controlled descriptors were used and PsycINFO Thesaurus was consulted for the PsycINFO database. The keywords were established after careful reading regarding the investigated theme. To widen the search strategy, a combination of controlled descriptors and keywords was made through Boolean operators. The Boolean operators AND and OR were used to obtain restrictive and additive combinations, respectively ${ }^{(33)}$. Also, the search was conducted using identified descriptors and those with a broadened sense, with no use of filters to preserve significant samples and assure lower risks of loss.

There was no date or language restriction in the search strategy. In addition to the electronic databases, secondary searches were made on other diverse sources, such as Clinical Trial Registry websites, including ClinicalTrials.gov (National Institutes of Health, NIH, USA), The Brazilian Clinical Trials Registry (via ReBEC Platform), and Google Scholar. Also, the list of final references in the included primary studies was manually analyzed to find relevant studies to be added. Chart 1 presents the final search strategy processed in the respective databases, conducted on January 24th, 2020.

Chart 1 - Search strategy in the consulted databases.

\begin{tabular}{|c|c|}
\hline Database & Search strategy \\
\hline $\begin{array}{l}\text { MEDLINE* } \\
\text { /PubMed } \\
01 / 24 / 2020^{* *}\end{array}$ & 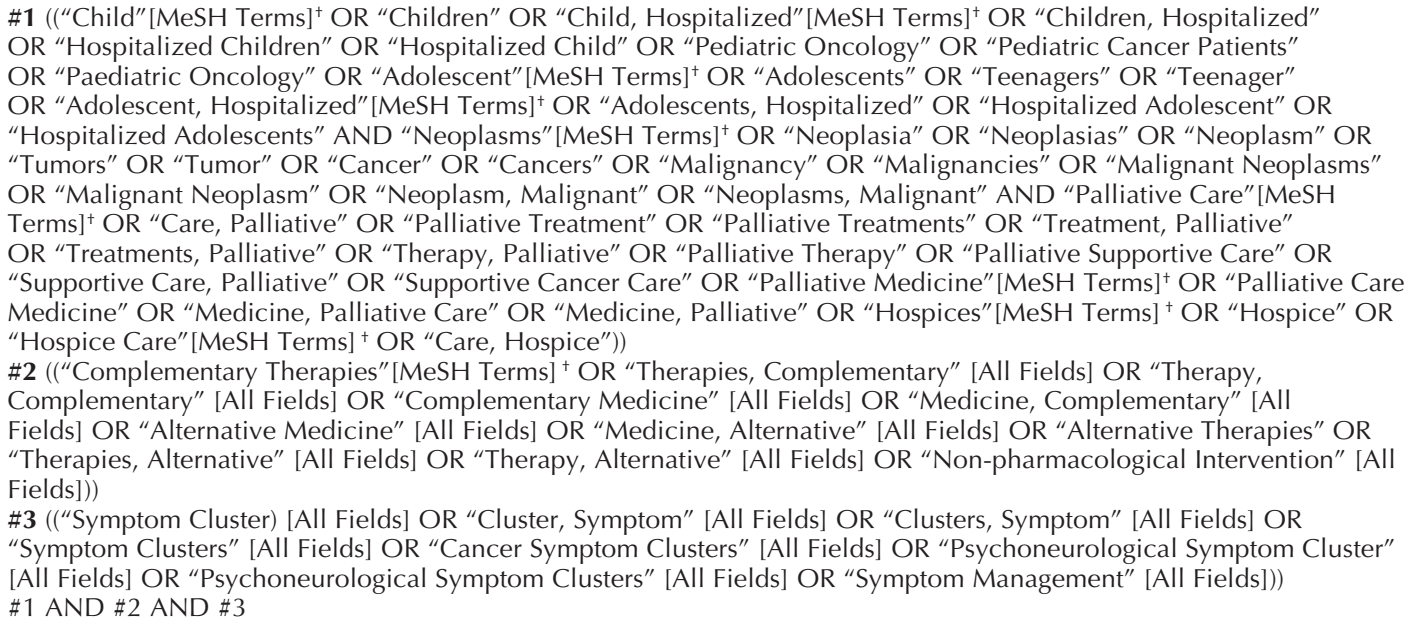 \\
\hline $\begin{array}{l}\text { CENTRAL } \\
\text { Cochrane } \neq \\
01 / 24 / 2020^{* *}\end{array}$ & 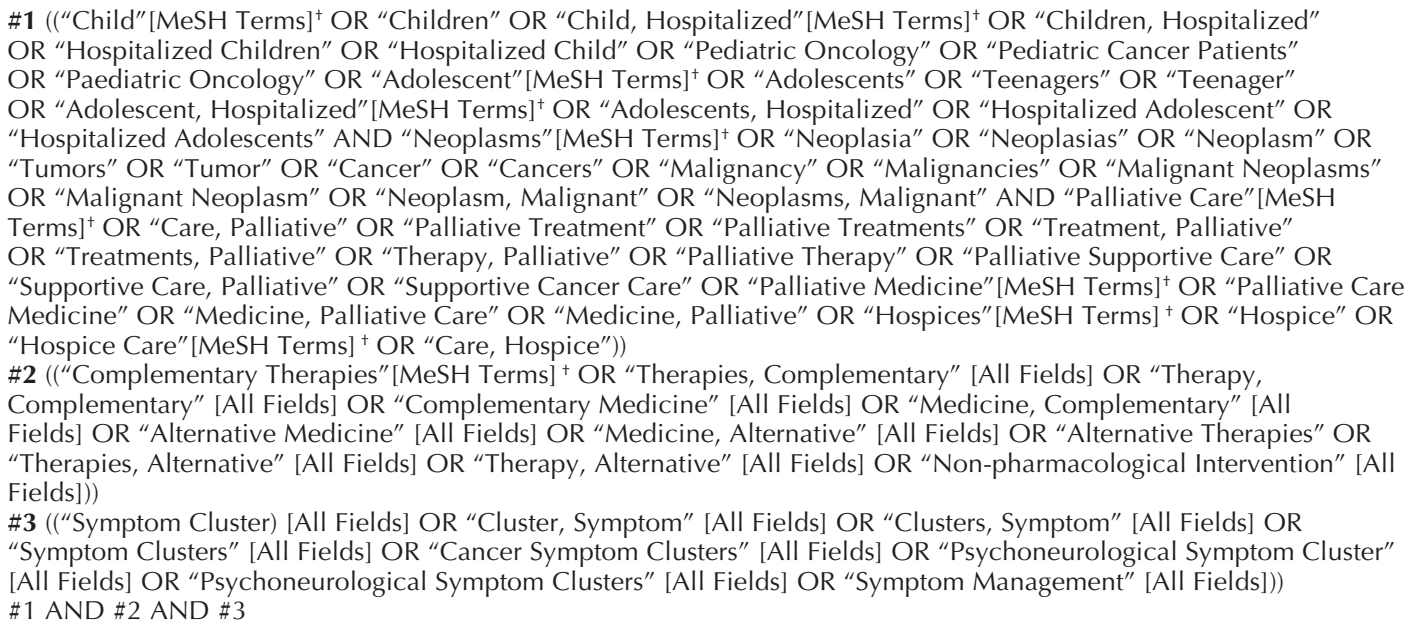 \\
\hline
\end{tabular}




\begin{tabular}{|c|c|}
\hline Database & Search strategy \\
\hline $\begin{array}{l}\text { Web of Science } \\
01 / 24 / 2020^{* *}\end{array}$ & 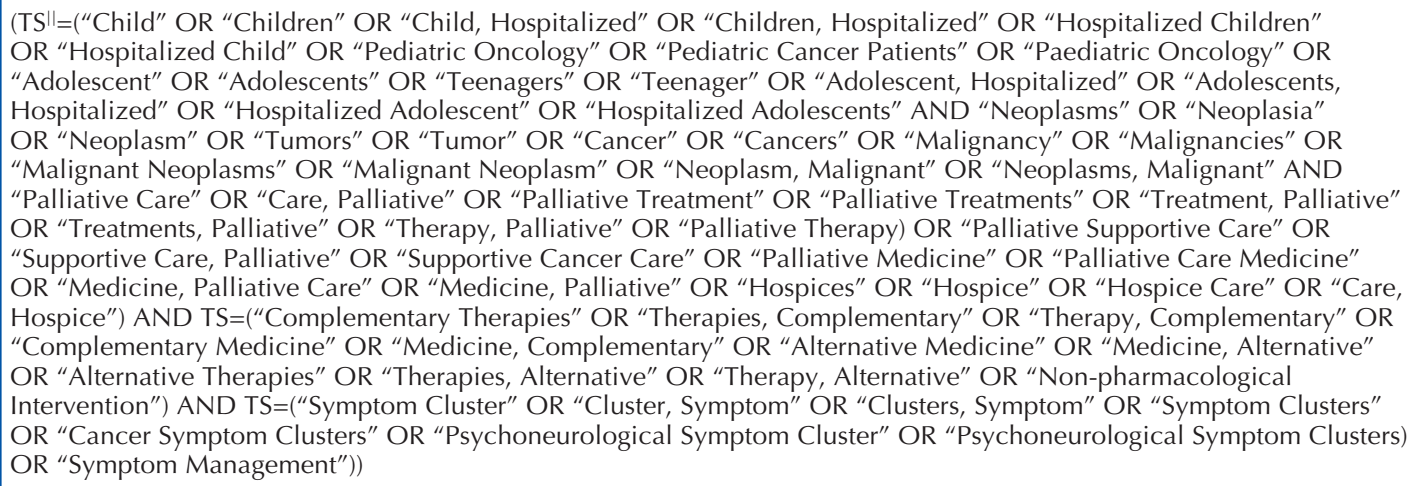 \\
\hline $\begin{array}{l}\text { PsyclNFO§ } \\
01 / 24 / 2020^{* *}\end{array}$ & $\begin{array}{l}\text { ("Child Care" [Thesaurus] OR "Pediatrics" [Thesaurus] OR "Adolescent Health" [Thesaurus] AND "Neoplasms" } \\
\text { [Thesaurus] OR "Terminal Cancer" [Thesaurus] OR "Oncology" [Thesaurus] AND "Palliative Care" [Thesaurus] } \\
\text { OR "Terminally III Patients" [Thesaurus] OR "Hospice" [Thesaurus] AND "Alternative Medicine" [Thesaurus] OR } \\
\text { "Complementary Therapies" [Thesaurus] OR "Non-pharmacological interventions" [Thesaurus] OR "Mind Body } \\
\text { Therapy" [Thesaurus] OR "Meditation" [Thesaurus] OR "Medicinal Herbs and Plants" [Thesaurus] OR "Massage" } \\
\text { [Thesaurus] OR "Hypnotherapy" [Thesaurus] OR "Holistic Health" [Thesaurus] OR "Dietary Supplements" [Thesaurus] } \\
\text { OR "Acupuncture" [Thesaurus] OR "Aromatherapy" [Thesaurus] OR "Faith Healing" [Thesaurus] AND "Symptoms" } \\
\text { [Thesaurus] OR "Symptoms Based Treatment")) }\end{array}$ \\
\hline
\end{tabular}

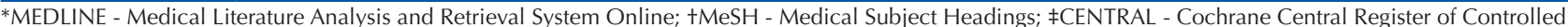
Trials; §PsycINFO - Psychology Information. "ITS - Topic. ${ }^{* *} 01 / 24 / 2020$ - Date on which the search strategy was conducted.

\section{ELIGIBILITY CRITERIA}

The included studies had a quantitative approach (observational studies and experimental studies) conducted with children and adolescents with cancer undergoing palliative care, from 0 to 19 years old, of both sexes, with a diagnosis of any type of malignant neoplasm; studies encompassing the effectiveness of any complementary therapy classified by The National Center for Complementary and Alternative Medicine (National Institutes of Health, USA), which categorizes them mainly as: use of natural products, practices of body and mind, and manipulation practices based on the body ${ }^{(23)}$ and whose primary outcome was the improvement of cancer symptom clusters. There was no date or language restriction in the search strategy. Excluded studies were qualitative, observational (cross-sectional, ecological, cohort, casecontrol - since these designs do not test the effectiveness of interventions), as well as all gray literature.

This part of the review used the reference manager EndNote ${ }^{\mathrm{TM}}$ to store, organize, and exclude duplicates to assure a systematic, comprehensive, and manageable search. The studies retrieved from each database and exported to EndNote $^{\mathrm{TM}}$ were later imported to the Rayyan ${ }^{\mathrm{TM}}$ app, developed by the Qatar Computing Research Institute ${ }^{(34)}$ - a tool to help selecting articles, especially in the phase of study eligibility and inclusion. The sample was selected by two independent reviewers blindly at the end of January 2020. After this selection, a third reviewer was responsible for analyzing and deciding (with the others) on the inclusion or exclusion of each article, especially regarding those with a conflicting decision, using the Rayyan ${ }^{\mathrm{TM}}$ App.

\section{DATA EXTRACTION}

The data were extracted using pre-established tools ${ }^{(35-39)}$ and included four domains: a) study identification, with data on the article's title, the journal's impact factor, country of the study's authors, year of publication, host institution of the study (hospital, university, research center, multicentric study or study in a single institution); conflicts of interest, funding; b) methodological characteristics (study design, study objective or research question or hypotheses, sample characteristics), e.g., sample size, age, baseline characteristics of experimental and control groups, recruitment method, dropouts, duration of follow-up, statistical analyses; c) main findings and implication for clinical practice and d) conclusions. For data extraction, two tables were elaborated in Microsoft Word ${ }^{\circledR}$ by two researchers independently to synthesize all data of the included studies. After this phase, the tables were compiled into one to carry on with the syntheses.

\section{Methodological assessment}

Initially, the evidence level was identified based on the study design. Thus, I was attributed to systematic reviews and meta-analyses of randomized clinical trials; II to randomized clinical trials; III to non-randomized controlled trials; IV to case-control, cohort, or cross-sectional studies; V to systematic reviews of qualitative or descriptive studies; VI to qualitative or descriptive studies, and VII to opinion by authorities and/or expert committee reports. This hierarchy classifies the levels I and II as strong, III to V as moderate, and VI to VII as weak ${ }^{(40)}$.

The evaluation of the methodological quality of the studies was defined as an essential process to establish internal validity, verifying possible biases and reliability of the identified evidence. In this systematic review, the methodological quality of the included studies was evaluated by two independent reviewers, using the tool Risk of Bias In Non-randomized Studies of Interventions (ROBINS-I). The tool ROBINS-I was developed recently and is particularly useful for the methodological 
evaluation of non-randomized clinical trials of interventions ${ }^{(41)}$. This tool is guided by seven domains of bias chronologically organized in three dimensions (pre-intervention, intervention, and post-intervention) and the interpretations of the domain level and general risk of biased judgement in ROBINS-I are classified into low, moderate, serious, or critical risk of bias ${ }^{(41)}$.

\section{DATA SYNTHESIS AND ANALYSIS}

The global judgement of ROBINS-I is systematized and attributed as follows: a) Low risk of bias, in which the study is comparable to a well-designed randomized trial (the study is considered as low risk of bias for all domains); b) Moderate risk of bias - the study is consistent with a non-randomized clinical trial design, but cannot be considered comparable to a well-designed randomized study (in this case, the study is considered as low or moderate risk of bias for all domains); c) Serious risk of bias - the study has some important problems (the study is considered as low or moderate risk of bias for most domains, but presents serious risk of bias in at least one of the domains); d) Critical risk of bias - the study is too problematic to provide any evidence (the study is considered as critical risk of bias in at least one domain); e) No information - when no information is available to provide grounds to any judgment of risk of bias (missing information on one or more domains $)^{(41)}$. Since most of the evaluated studies presented significant methodological differences, a qualitative synthesis of the data was opted for this systematic review.

\section{RESULTS}

\section{Study Selection}

The searches on four electronic databases, as well as manual search on other sources, led to 778 studies. Out of these, 19 studies were duplicated in the databases and were removed in the reference manager EndNote ${ }^{\mathrm{TM}}$. The studies which made it to the selection phase amounted to 759; these proceeded to the process of screening by title and abstract. In this step, conducted in Rayyan ${ }^{\mathrm{TM}}$ App, 749 studies were excluded for not meeting the pre-established inclusion criteria. Exclusion due to title or abstract resulted in the selection of 10 studies, which proceeded to complete reading. After the step of exhaustive complete reading of the studies, other five studies were excluded, resulting thus in five articles to be included for qualitative synthesis and analysis, as shown in Figure 1.
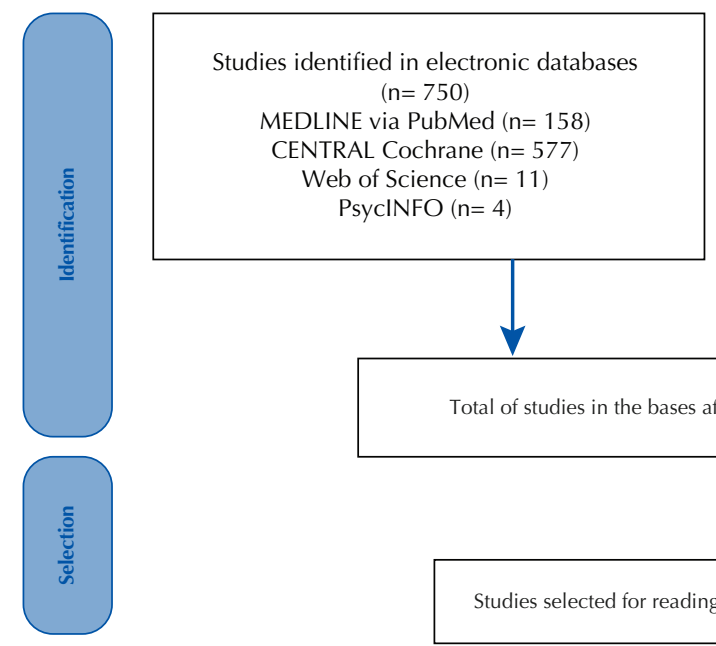

Total of studies in the bases after removing duplicates $(\mathrm{n}=759)$
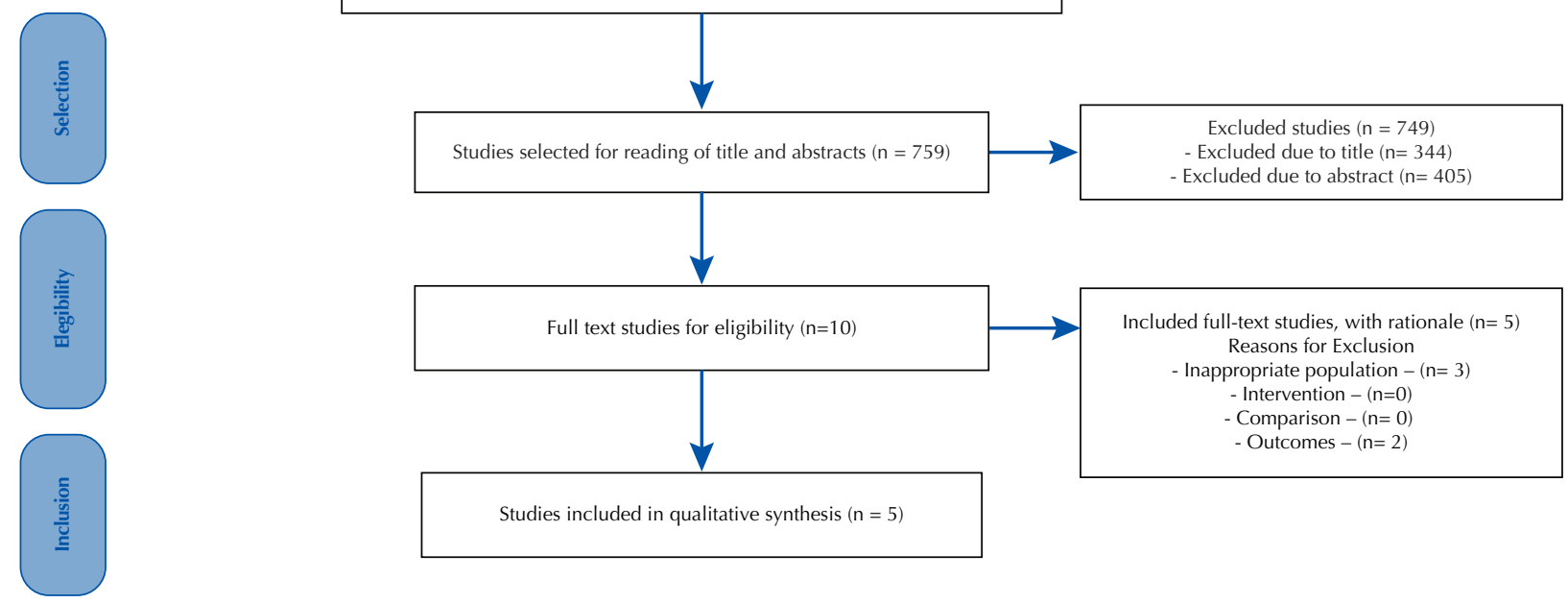

Studies included in qualitative synthesis $(\mathrm{n}=5)$

Figure 1 - PRISMA Flowchart ${ }^{(31)}$ for study selection.

\section{StUdY CHARACTERIZATION}

Regarding the characteristics of the five included studies, the date of publication was verified to range from 2000 to $2020^{(42-46)}$, all of them were published in English in four different countries (Germany, Canada, United States, and Israel), and had a quasi-experimental design. Chart 2 synthesizes chronologically the main characteristics of the studies included in the qualitative synthesis. 
Chart 2 - Characteristics of quasi-experimental studies included in the systematic review.

\begin{tabular}{|c|c|c|c|c|c|c|}
\hline $\begin{array}{l}\text { Reference/ } \\
\text { Country }\end{array}$ & Objective & Sample & $\begin{array}{l}\text { Complementary therapy / } \\
\text { Intervention protocol }\end{array}$ & $\begin{array}{l}\text { Clinical } \\
\text { outcomes/ } \\
\text { Symptom clusters }\end{array}$ & Instruments & Main results \\
\hline $\begin{array}{l}\text { Janben et } \\
\text { al. } 2000^{(42)} \\
\text { Germany }\end{array}$ & $\begin{array}{l}\text { To evaluate } \\
\text { the effects } \\
\text { of boswellic } \\
\text { acid }\left(\mathrm{H} 15^{*}\right) \\
\text { administered to } \\
\text { children with } \\
\text { progressive or } \\
\text { recurrent brain } \\
\text { tumors receiving } \\
\text { palliative care }\end{array}$ & $\begin{array}{l}19 \text { patients } \\
(11 \text { boys and } \\
8 \text { girls) } \\
\text { Age: } 6 \\
\text { months to } 18 \\
\text { years } \\
\text { (mean age: } \\
8.4 \text { years old) }\end{array}$ & $\begin{array}{l}\text { Use of boswellic acid }\left(\mathrm{H} 15^{*}\right) / \\
\text { The oral dose of } \mathrm{H} 15 \text { was of } \\
40 \pm 126(\text { median }=77) \mathrm{mg} / \mathrm{kg} \\
\text { weight/day administered in } 3 \\
\text { doses during } 1 \pm 26 \text { (median }=9 \text { ) } \\
\text { months. } \\
\text { Fourteen patients received } \\
\mathrm{H} 15^{*} \text { as monotherapy, whereas } \\
5 \text { patients received } \mathrm{H} 15^{*} \text { with } \\
\text { additional conventional therapy }\end{array}$ & $\begin{array}{l}\text { - Clinical } \\
\text { outcomes: } \\
\text { muscular } \\
\text { strength, } \\
\text { hemiparesis, } \\
\text { ataxia, and } \\
\text { weight gain } \\
\text { - Symptom } \\
\text { clusters: } \\
\text { headache, } \\
\text { fatigue, loss of } \\
\text { appetite, and } \\
\text { nausea }\end{array}$ & $\begin{array}{l}\text { Subjective } \\
\text { analysis } \\
\text { through the } \\
\text { oncologists' } \\
\text { observations }\end{array}$ & $\begin{array}{l}\text { No adverse effects were } \\
\text { attributed to } \mathrm{H}^{*} 5^{*} \text { in } 19 \\
\text { patients. } \\
\text { Children who reported } \\
\text { an improvement in } \\
\text { their general health } \\
\text { state amounted to } \\
5 / 19 ; 3 / 17 \text { patients } \\
\text { presented a mainly } \\
\text { transient improvement of } \\
\text { neurological symptoms, } \\
\text { such as hemiparesis and } \\
\text { ataxia. }\end{array}$ \\
\hline $\begin{array}{l}\text { Thrane et } \\
\text { al. } 2017^{(43)} \\
\text { USA }\end{array}$ & $\begin{array}{l}\text { To examine the } \\
\text { viability and } \\
\text { acceptability of } \\
\text { Reiki in children } \\
\text { undergoing } \\
\text { palliative } \\
\text { treatment and } \\
\text { the effect of Reiki } \\
\text { therapy on pain } \\
\text { and anxiety }\end{array}$ & $\begin{array}{l}16 \text { patients }(8 \\
\text { verbal and } 8 \\
\text { non-verbal) } \\
(11 \text { girls and } \\
5 \text { boys) } \\
\text { Age: } 7 \text { to } 16 \\
\text { years old } \\
\text { (mean age: } \\
12.6 \text { years } \\
\text { old) }\end{array}$ & $\begin{array}{l}\text { Use of Reiki / } \\
\text { The intervention consisted of } \\
\text { two 24-minute Reiki sessions } \\
\text { at the child's home, with a } \\
\text { minimum of } 1 \text { and a maximum } \\
\text { of } 3 \text { days between sessions. } \\
\text { Each Reiki session used a } \\
\text { protocol of } 12 \text { hand positions } \\
\text { performed for } 2 \text { minutes each. } \\
\text { The child was comfortably } \\
\text { dressed and the parents were } \\
\text { invited to watch the sessions. } \\
\text { The interventionist was a } \\
\text { pediatric nurse with } 12 \text { years } \\
\text { of experience, who wrote } \\
\text { down in a registry the number } \\
\text { of minutes for the session, } \\
\text { including any deviations } \\
\text { from protocol or uncommon } \\
\text { occurrences }\end{array}$ & $\begin{array}{l}\text { - Clinical } \\
\text { outcomes: heart } \\
\text { and respiratory } \\
\text { rate } \\
\text { - Symptom } \\
\text { clusters } \\
\text { pain and anxiety }\end{array}$ & $\begin{array}{l}\text { - VASt } \\
\text { - Wong-Baker } \\
\text { FACES }{ }^{\circledR} \text { Pain } \\
\text { Scale } \\
\text { - The } \\
\text { Children's Fear } \\
\text { Scale } \\
\text { - Children's } \\
\text { Anxiety and } \\
\text { Pain Scale }\end{array}$ & $\begin{array}{l}\text { All mean scores of the } \\
\text { outcome variables (pain, } \\
\text { anxiety, heart, and } \\
\text { respiratory rate) decreased } \\
\text { after treatment with } \\
\text { the two Reiki sessions. } \\
\text { Significant reductions in } \\
\text { pain during treatment } 1 \text { in } \\
\text { non-verbal children ( } p= \\
.063 \text { ) and for respiratory } \\
\text { rate of treatment } 2 \text { in } \\
\text { verbal children (p = } \\
.009 \text { ). The size of Cohen's } \\
\text { effects was medium and } \\
\text { high for most outcome } \\
\text { measurements. }\end{array}$ \\
\hline $\begin{array}{l}\text { Weekly } \\
\text { et al. } \\
2019^{(44)} \\
\text { USA }\end{array}$ & $\begin{array}{l}\text { To explore } \\
\text { the impact of } \\
\text { therapeutic } \\
\text { massage on } \\
\text { symptom overload } \\
\text { and use of } \\
\text { medication in } \\
\text { pediatric patients } \\
\text { undergoing } \\
\text { palliative } \\
\text { care, describe } \\
\text { the impact of } \\
\text { therapeutic } \\
\text { massage on the } \\
\text { suffering of the } \\
\text { family caregiver } \\
\text { and report the } \\
\text { perception of } \\
\text { the nursing team } \\
\text { of the impact } \\
\text { of therapeutic } \\
\text { massage for the } \\
\text { children and their } \\
\text { families }\end{array}$ & $\begin{array}{l}53 \text { patients } \\
\text { ( } 17 \text { girls and } \\
36 \text { boys) } \\
\text { Age: } 6 \\
\text { months to } 8 \\
\text { years } \\
\text { (mean age: } \\
3.8 \text { years old) }\end{array}$ & $\begin{array}{l}\text { Use of therapeutic massage / } \\
\text { The massage intervention } \\
\text { occurred during a scheduled } \\
\text { period of } 30 \text { minutes in the } \\
\text { participant's hospital room. } \\
\text { The massage was performed } \\
\text { by a certified pediatric } \\
\text { massage therapist, with a } \\
\text { focus on hands, feet, arms, } \\
\text { scalp, head, and shoulders } \\
\text { of the participants. Relaxing } \\
\text { music was used during the } \\
\text { intervention to minimize } \\
\text { the noise from the hospital } \\
\text { ward. The family caregivers } \\
\text { were encouraged to watch } \\
\text { the intervention. The mean } \\
\text { duration of a massage was } \\
10.5 \text { minutes, with a minimum } \\
\text { duration of } 3 \text { minutes and } \\
\text { maximum duration of } 22 \\
\text { minutes. }\end{array}$ & $\begin{array}{l}\text { - Clinical } \\
\text { outcomes: use of } \\
\text { pain medication } \\
\text { "if necessary" } \\
\text { - Symptom } \\
\text { clusters } \\
\text { pain, anxiety, } \\
\text { dyspnea, and } \\
\text { nausea }\end{array}$ & $\begin{array}{l} \\
\\
\text { - NCCN§ } \\
\text { Distress } \\
\text { Thermometer } \\
\text { Scale } \\
\text { - FACES } \\
\text { Pictorial Scale } \\
\text { - BARF|| } \\
\text { Pictorial Scale } \\
\text { - Dalhousie } \\
\text { Dyspnea Scale } \\
\text { - McMurtry } \\
\text { Anxiety Scale } \\
\text { - FLACC } 9 \\
\text { Scale }\end{array}$ & 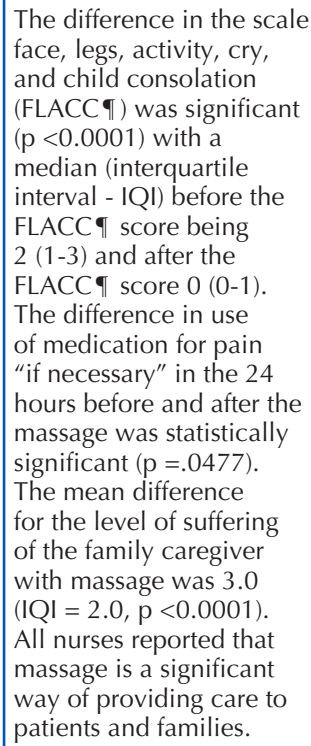 \\
\hline
\end{tabular}




\begin{tabular}{|c|c|c|c|c|c|c|}
\hline $\begin{array}{l}\text { Reference/ } \\
\text { Country }\end{array}$ & Objective & Sample & $\begin{array}{l}\text { Complementary therapy / } \\
\text { Intervention protocol }\end{array}$ & $\begin{array}{l}\text { Clinical } \\
\text { outcomes/ } \\
\text { Symptom clusters }\end{array}$ & Instruments & Main results \\
\hline $\begin{array}{l}\text { Ofir et al., } \\
2019^{(45)} \\
\text { Israel }\end{array}$ & $\begin{array}{l}\text { To analyze the } \\
\text { short-term efficacy } \\
\text { and safety of } \\
\text { Cannabis sativa } \\
\text { (marijuana) (M)+† } \\
\text { in pediatric } \\
\text { oncology patients } \\
\text { undergoing } \\
\text { palliative care }\end{array}$ & $\begin{array}{l}50 \text { patients } \\
\text { (19 girls and } \\
31 \text { boys) } \\
\text { Age: } 7 \\
\text { months to } 19 \\
\text { years } \\
\text { (mean age: } \\
13 \text { years old) }\end{array}$ & $\begin{array}{l}\text { Use of marijuana / } \\
\text { The first dose of marijuana } \\
\text { for all patients was } 20 \text { grams } \\
\text { per month (cannabis through } \\
\text { dry inflorescence) used for } \\
\text { inhalation / smoking or a basis } \\
\text { for oil production. } \\
\text { Marijuana (M)+t was offered } \\
\text { to } 30 \text { patients through oil } \\
\text { drops }(60 \%) \text { and to } 11 \text { through } \\
\text { smoking }(22 \%) \text {, followed by } \\
\text { vaporization, capsules, or } \\
\text { combination of various routes }\end{array}$ & $\begin{array}{l}\text { - Clinical } \\
\text { outcomes: quality } \\
\text { of life } \\
\text { - Symptom } \\
\text { clusters } \\
\text { nausea and } \\
\text { vomit, loss of } \\
\text { appetite, mood, } \\
\text { sleep disorders, } \\
\text { and pain }\end{array}$ & $\begin{array}{l}\text { - VAS+ } \\
\text { - NRS** } \\
\text { - FLACC }\end{array}$ & $\begin{array}{l}\text { Positive effects were } \\
\text { reported by children } \\
\text { and parents in } 80 \% \text { of } \\
\text { the cases related to the } \\
\text { symptoms nausea and } \\
\text { vomit, sleep disorders, } \\
\text { pain, appetite, and mood. } \\
\text { Five (10\%) patients who } \\
\text { smoked reported burning } \\
\text { throat and anxiety attacks; } \\
4 \% \text { reported stomach } \\
\text { pain, but it was not clear } \\
\text { whether these complaints } \\
\text { were caused by marijuana } \\
\text { (M)t+ or by the children's } \\
\text { medical conditions. }\end{array}$ \\
\hline $\begin{array}{l}\text { Genik et al. } \\
2020^{(46)} \\
\text { Canada }\end{array}$ & $\begin{array}{l}\text { To perform an } \\
\text { intervention } \\
\text { of therapeutic } \\
\text { massage to } \\
\text { determine the } \\
\text { acceptability of } \\
\text { the intervention } \\
\text { and its initial } \\
\text { effects on pain } \\
\text { classification, } \\
\text { reduction of } \\
\text { worry, and quality } \\
\text { of life }\end{array}$ & $\begin{array}{l} \\
8 \text { patients } \\
\text { (3 girls and } 5 \\
\text { boys) } \\
\text { Age: } 10 \text { to } 17 \\
\text { years } \\
\text { (mean age= } \\
14.5 \text { years) }\end{array}$ & 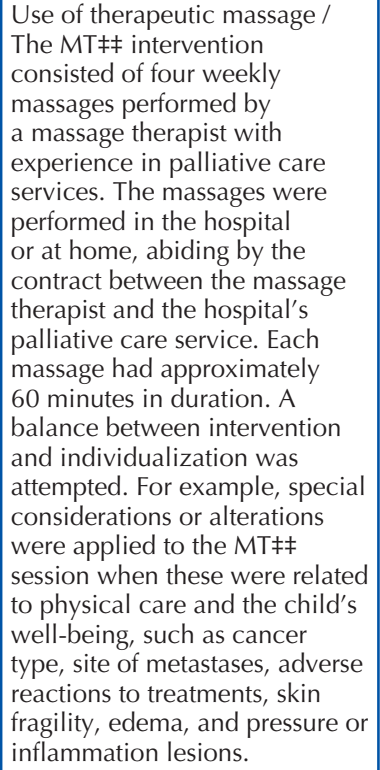 & $\begin{array}{l}\text { - Clinical } \\
\text { outcomes: quality } \\
\text { of life } \\
\text { - Symptom } \\
\text { clusters } \\
\text { pain and worry }\end{array}$ & 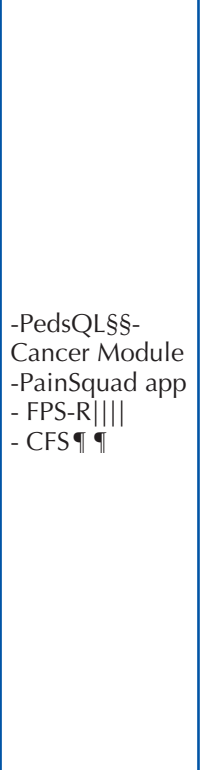 & $\begin{array}{l}\text { The participants reported } \\
\text { significant pain reductions } \\
\text { after two MT\#キ sessions ( } p \\
=0.03 \text { ) and in worry after } \\
\text { one session ( } p=0.03 \text { ). } \\
\text { No statistically significant } \\
\text { differences were found } \\
\text { for symptoms pain and } \\
\text { quality of life between } \\
\text { baseline and follow-up } \\
(p>0.05)\end{array}$ \\
\hline
\end{tabular}

Acronyms: *H15- Special extract of Boswellia Serrata; +VAS - Visual Analogue Scale; §NCCN - The National Comprehensive Cancer Network; ||BARF - Baxter Animated Retching Faces; I FLACC - Face, Legs, Activity, Cry, Consolability; ** NRS- Numerical Rating Scale; +tM- Marijuana; \#¥MT- Massage Therapy; $\S \S$ PedsQL- Pediatric Quality of Life Inventory; II||FPS-R - The Faces Pain Scale; $\uparrow$ ฯ CFS- The Clinical Frailty Scale.

\section{CANCER SYMPTOM CLUSTERS EVALUATED IN THE STUDIES}

The total of research participants in the studies ${ }^{(42-46)}$ included in this systematic review was 146 patients, and samples varied from 6 months to 19 years of age (mean age of 10 years and a half). With regards to the use of complementary therapies in the included studies, two were verified to use therapeutic massage ${ }^{(4,46)}$, one used reiki ${ }^{(43)}$; one study used boswellic acid ${ }^{(42)}$ and another one ${ }^{(45)}$ evaluated the use of Cannabis sativa (marijuana) for the management of symptom clusters in children and adolescents with cancer undergoing palliative care.

Regarding the symptom clusters evaluated in the five included studies, the oncological pain was verified to be the most evaluated symptom by four studies ${ }^{(43-46)}$, followed by the symptom nausea, evaluated by three studies ${ }^{(42,44-45)}$. The symptoms loss of appetite ${ }^{(42,45)}$ and anxiety ${ }^{(43-44)}$ were also evaluated by two studies, respectively. Cancer-related fatigue was evaluated by a single study ${ }^{(42)}$, as was the symptom sleep disorder ${ }^{(45)}$. The most often evaluated clinical outcome was quality of life, analyzed in two studies ${ }^{(45-46)}$. Regarding the time of follow-up, all studies presented a short period, with intervention protocols varying among the studies ${ }^{(42-46)}$. None of the five included studies presented a control group or randomization of research participants. The instruments used to evaluate the symptom clusters in children and adolescents with cancer undergoing palliative care, only one study was verified not to use validated instruments to measure such symptom groups, using subjective analysis through the oncologists' observation ${ }^{(42)}$. The most often reported instruments were $\operatorname{VAS}^{(43,45)}, \mathrm{FACES}^{(43-44)}$, and $\mathrm{FLACC}^{(44-45)}$.

\section{ChaRACTERISTICS OF STUDY INTERVENTIONS}

Therapeutic massage was evaluated in two promising studies $^{(4,46)}$. In one study, there was an acceptability and pre-/posttest efficacy associated to the impact of therapeutic massage on pain, worry, and the overall quality of life of patients ${ }^{(46)}$. The participants reported significant short-term reductions in pain $(p=0.03)$ (after two sessions of therapeutic massage) and 
worry ( $p=0.03$ ) (after one session), when compared to baseline measurements ${ }^{(46)}$. The other study on therapeutic massage ${ }^{(44)}$ had as a main characteristic the verbalization of children on the intervention, such as "I want to feel better" or "I want to relax" before the first session of therapeutic massage. Family caregivers were encouraged to watch the patients' massage to obtain instructions on massage techniques which could be used by the family. Patients undergoing pediatric palliative care who received a massage completed the National Comprehensive Cancer Network Distress Thermometer Scale 5 minutes before and after the intervention. The participants received a validated visual scale spreadsheet for each symptom, suiting their age. The spreadsheet was provided to the child with numerical classifications in each of the following figures: FACES pictorial scale, Baxter Animated Retching Faces (BARF), Dalhousie Dyspnea Scale, McMurtry Faces Anxiety Scale, and Face, Legs, Activity, Cry, Consolability Scale (FLACC) for non-verbal children or those with cognitive problems pre- and post-massage ${ }^{(44)}$. In this study, there was a statistically significant difference in the use of medication for pain "if necessary" in the 24 hours before and after the massage $(\mathrm{p}=.0477)^{(44)}$.

The application of the Reiki intervention required informed consent from parents and the children's consent, and the Reiki therapy sessions were carried out as desired by the family. Pain, anxiety, heart, and respiratory rate were registered immediately before and after each Reiki therapy session $^{(43)}$. This study's findings point that all the mean scores of the outcome variables (pain, anxiety, heart, and respiratory rate) reduced after the two Reiki sessions. Also, pain reduced significantly among non-verbal children $(\mathrm{p}=.063)^{(43)}$.

The use of boswellic acid as a palliative effect was evaluated for clinical and radiological responses. The subjective relief of symptoms such as headache, fatigue, loss of appetite, and nausea was monitored. Objective criteria such as vomit, body weight, and evolution of neurological deficits such as paresis, ataxia, impaired coordination, and sensory deficits were documented by repeated oncological exams ${ }^{(42)}$. In this study, no adverse effects which could be attributed to boswellic acid were observed in the 19 patients; $26 \%(n=5)$ reported an improvement in their overall health status with the use of boswellic acid ${ }^{(42)}$.

The other intervention used Cannabis sativa (marijuana extract). After receiving a license in that country (Israel), parents and children were trained on how to use the medication and instructed of possible side-effects. Specifically, the parents were informed orally by the assistant physician of the possible side-effects of marijuana, such as an increase in sleepiness, slight reduction of cognitive skills and concentration, and allergic reactions, such as cutaneous eruption and wheezing, as well as dry mouth and dizziness. The marijuana was manufactured with support of the Israeli Ministry of Health. Marijuana was introduced and monitored gradually in patients to provide symptom relief while avoiding dependence ${ }^{(45)}$. This study with no control group had positive effects reported by children and parents in $80 \%$ of the cases regarding the symptoms nausea and vomit, sleep disorders, pain, appetite, and mood. However, 14\% patients who smoked reported burning throat, anxiety attacks, and stomach pain ${ }^{(45)}$.

\section{INTERNAL VALIDITY OF THE INCLUDED STUDIES}

Regarding the risk of bias of the studies selected and evaluated by the tool ROBINS-I, which evaluates the internal validity of non-randomized clinical trials of interventions, most studies $(n=3)^{(42,44-45)}$ were classified as serious risk of bias, i.e., such studies presented important problems (and this occurs when the study is considered as low or moderate risk of bias for most domains, but presents serious risk of bias in at least one of the domains of ROBINS-I). The other two studies were judged as being moderate and with a higher reported methodological consistency ${ }^{(43,46)}$. No study was classified as low risk of bias, receiving a score in all domains for this category. Among the domains of ROBINS-I, those which were classified as serious were related to selection biases (participant recruitment and incomplete data/losses) and measurement biases (classification and intervention bias). In Chart 3, the methodological evaluation of each study is shown in detail in a chronological order.

Chart 3 - Evaluation by consensus of ROBINS-I between two reviewers per bias domain.

\begin{tabular}{|c|c|c|c|c|c|c|c|c|}
\hline \multirow[b]{2}{*}{ Study } & \multicolumn{7}{|c|}{ *Domains ROBINS-I } & \multirow[b]{2}{*}{$\begin{array}{l}\text { Overall } \\
\text { judgment } \\
\text { ROBINS-I }\end{array}$} \\
\hline & $\begin{array}{c}\text { Confounding } \\
\text { bias }\end{array}$ & $\begin{array}{c}\text { Participant } \\
\text { selection bias }\end{array}$ & $\begin{array}{c}\text { Classification } \\
\text { of intervention } \\
\text { bias }\end{array}$ & $\begin{array}{l}\text { Bias due to } \\
\text { intervention } \\
\text { deviations }\end{array}$ & $\begin{array}{c}\text { Incomplete } \\
\text { data bias }\end{array}$ & $\begin{array}{c}\text { Outcome } \\
\text { measurement } \\
\text { bias }\end{array}$ & $\begin{array}{c}\text { Selective } \\
\text { outcome } \\
\text { reporting bias }\end{array}$ & \\
\hline $\begin{array}{l}\text { Janben et } \\
\text { al. }{ }^{(42)}\end{array}$ & Moderate & Serious & Serious & Moderate & Serious & Serious & Moderate & Serious \\
\hline $\begin{array}{l}\text { Thrane et } \\
\text { al. }{ }^{(43)}\end{array}$ & Moderate & Moderate & Low & Low & Low & Moderate & Low & Moderate \\
\hline $\begin{array}{l}\text { Weekly et } \\
\text { al. }{ }^{(44)}\end{array}$ & Moderate & Serious & Moderate & Moderate & Serious & Moderate & Moderate & Serious \\
\hline Ofir et al. ${ }^{(45)}$ & Moderate & Moderate & Serious & Serious & Moderate & Moderate & Moderate & Serious \\
\hline $\begin{array}{l}\text { Genik et } \\
\text { al.(46) }\end{array}$ & Moderate & Moderate & Moderate & Moderate & Moderate & Moderate & Moderate & Moderate \\
\hline
\end{tabular}

Acronyms:*ROBINS-I, Risk of Bias In Non-randomized Studies.(41) ** The global judgement of ROBINS-I is systematized and attributed as follows: a) Low risk of bias, in which the study is comparable to a well-designed randomized trial (the study is considered as low risk of bias for all domains); b) Moderate risk of bias - the study is consistent with a non-randomized study design, but cannot be considered comparable to a well-designed randomized study (in this case, the study is considered as low or moderate risk of bias for all domains); c) Serious risk of bias - the study has some important problems (the study is considered as low or moderate risk of bias for most domains, but presents serious risk of bias in at least one of the domains); d) Critical risk of bias - the study is too problematic to provide any evidence (the study is considered as critical risk of bias in at least one domain); e) No information - when no information is available to provide grounds to any judgment of risk of bias (missing information on one or more domains) ${ }^{(41)}$. 


\section{DISCUSSION}

This systematic review aimed at synthesizing and critically evaluating the evidence on complementary therapies effectivity in symptom cluster management of children and adolescents with cancer undergoing palliative care. Overall, out of five quasi-experimental studies which met the inclusion criteria, two used therapeutic massage ${ }^{(44,46)}$, one used reiki ${ }^{(43)}$, one evaluated the effect of boswellic $\operatorname{acid}^{(42)}$, and another one evaluated the effects of Cannabis sativa (marijuana) $)^{(45)}$. Three studies (using therapeutic massage and Reiki) presented statistically significant results for managing the cluster pain-anxiety-worry-dyspnea.

\section{TheRAPEUTIC MASSAGE}

Care directed at children and adolescents concentrated on optimization of quality of life and reduction of suffering for those with severe diseases, including cancer ${ }^{(44,47)}$. Unfortunately, management of diverse cancer symptom clusters experienced by this population in palliative care are frequently mismanaged, focusing mainly on pharmacological intervention, which results in increased suffering and a reduced quality of life ${ }^{(48-49)}$. To meet the psychosocial well-being and manage the overload of cancer symptom clusters which are concomitantly faced by these patients, complementary therapies must be incorporated, e.g., therapeutic massage ${ }^{(44,48)}$.

Therapeutic massage is a low-risk manipulative physical intervention included among complementary health approaches ${ }^{(49)}$. This is also a low-cost intervention and is currently being used in pediatric oncology services, showing positive effects in adults and children with chronic diseases, including cancer ${ }^{(23,50-51)}$. Its administration is accessible and easily performed, providing the benefits of muscle relaxation and, consequently, tension reduction. Therapeutic massage had positive effects on diverse health conditions, such as in the integumentary, musculoskeletal, nervous, circulatory, lymphatic, respiratory, and endocrine systems ${ }^{(49)}$. Symptoms such as pain, worry, and fear are common in children with cancer under palliative treatment and the most appropriate management of these symptoms is particularly hard ${ }^{(47,52)}$. One possibility is the use of therapeutic massage $e^{(50-51)}$.

In this review, two studies evaluating the use of therapeutic massage presented positive and effective results ${ }^{(44,46)}$. The difference between the scores in the FLACC scale was significant $(p<0.0001)$ comparing the moments before and after the intervention, showing an improvement in the overall comfort of the child after receiving therapeutic massage. The difference in the use of medication for pain "if necessary" in the 24 hours before and after the massage was statistically significant ( $\mathrm{p}=.0477)$, and such need was reduced after the intervention $^{(44)}$. In the other study about therapeutic massage, the participants reported significant reductions in pain after two sessions of therapeutic massage $(p=0.03)$ and in the worry after one session $(\mathrm{p}=0.03)^{(46)}$.

These findings are in line with two recent systematic reviews ${ }^{(53-54)}$. The first review which aimed at understanding the effects of therapeutic massage on children with cancer has shown that the authors of the evaluated primary studies used different massage techniques (Swedish massage, effleurage, petrissage, frictions, pressure), obtaining benefits in symptoms (pain, nausea, stress, and anxiety reduction) and increase in leukocytes and neutrophils ${ }^{(53)}$. The second systematic review of clinical trials in the pediatric oncology population identified nine studies investigating the efficacy of therapeutic massage and found encouraging and beneficial evidence for various symptoms, especially for oncologic pain and anxiety(54).

Regarding the symptom pain, authors ${ }^{(55)}$ show that pain perception by patients undergoing palliative care is reduced and lasts for 18 hours after the application of therapeutic massage, whereas other researchers ${ }^{(56)}$ indicate that the intervention, conducted by a nurse with expertise in therapeutic massage for 45 minutes in children with osseous metastases reduces anxiety and pain and its effects are long-lasting. Based on previous studies with both adult and pediatric populations with chronic diseases, including cancer, therapeutic massage may help reducing unpleasant symptoms, such as pain, fear, anxiety, and fatigue, as well as improving the individual's functional capacity ${ }^{(23,50,51,54,57)}$.

\section{REIKI THERAPY}

Concerning the use of Reiki as a complementary therapy for the management of symptom clusters in children and adolescents with cancer undergoing palliative care, the findings of the study evaluating Reiki therapy in this population shows that all mean scores for the outcome variables (pain, anxiety, heart and respiratory rate) reduced after two Reiki sessions $(\mathrm{p}=.063)^{(43)}$.

The findings in this review corroborate a recently published pilot study, conducted to test the viability and efficacy of Reiki to provide pain relief among pediatric patients submitted to hematopoietic stem-cell transplants. In this study, the effect of 88 sessions of Reiki therapy in nine patients was analyzed through a short, medium, and long-term perspective. Variance analysis of repeated measures has revealed a significant difference between the three periods $(\mathrm{F}=17.17$ $\mathrm{p}<0.0001$ ); pain reduction was achieved during the experimental period in short and medium term, whereas in the follow-up period the level of pain was stable ${ }^{(58)}$. The authors of the pilot study have concluded that nurses trained in pediatric and adolescent oncology may insert Reiki into their clinical practice as a valid instrument to reduce suffering caused by cancer in children and adolescents. Still, studies on Reiki are emphasized to be scarce so far, especially for the pediatric and adolescent oncology population undergoing palliative care ${ }^{(43)}$.

Among various complementary therapies, those related to energy are particularly promising ${ }^{(58-59)}$. Reiki has no religious doctrine and does not depend on any innate personal capacity for cure; it is taught by Reiki masters and practiced by those who have learned Reiki hand positions and who were attuned to open their body's energy channels ${ }^{(60)}$. Reiki is a relaxing form of cure therapy which is applied through a gentle, non-invasive, non-manipulative touch ${ }^{(61)}$. It is defined by the National Center for Complementary and Integrative 
Health $(\mathrm{NCCIH})$ as "a complementary health approach in which practitioners place their hands lightly on or just above a person, with the goal of helping to facilitate the person's own healing response"(61).

Non-invasive care that the Reiki therapy approach evokes is appropriate even for very fragile patients ${ }^{(59)}$, such as pediatric patients undergoing palliative care. Among adult patients, Reiki therapy emphasized relevant and positive clinical properties $^{(62)}$, but, among children, studies are still too scarce to draw precise conclusions ${ }^{(58)}$. The few available pediatric studies discuss Reiki treatment for hospitalized children caregivers, especially those submitted to surger $y^{(63-65)}$. Reiki as a complementary therapy in pediatric oncology has been growing worldwide, but still requires more robust evidence to be better accepted by the scientific community ${ }^{(58)}$.

\section{BOSWELLIC ACID}

Boswellic acids are extracted from the resin of the Boswellia tree ${ }^{(42)}$. Salai Guggal is the Indian incense prepared with Boswellia serrata, which is still used in traditional popular Indian medicine (Ayurveda) in treating inflammatory and rheumatic diseases. In biochemical analysis, this Indian incense represented a standardized mixture of various boswellic acids and a minor component of dienes and terpenes $^{(66)}$. In vitro, acetyl-11-keto-boswellic acid was shown to be the most efficient component of all boswellic acids ${ }^{(67)}$.

Extracts from Boswellia serrata gum resin and some of their constituents affect the immune system in different manners. During cell defense, boswelic acids seem to increase lymphocyte proliferation, whereas higher concentrations are inhibitive. Also, boswellic acids increase macrophage phagocytosis. Boswellic acids affect the cell defense system by interacting with cytokines production and release, inhibiting the activation of NF kappa B. Consequently, a negative regulation of TNF- $\alpha$ and a reduction of pro-inflammatory cytokines IL-1 $\beta$, IL-2, IL-4, IL-6 e IFN- $\gamma$, modulated by boswellic acids, have been reported ${ }^{(68)}$.

Regarding the use of boswellic acid as a complementary therapy, the one study which met this review's criteria evaluated the palliative effect of this acid in clinical and radiological response, showing no adverse effects which could be attributed to boswellic acid in the 19 patients; 26\% ( $n=5)$ reported an improvement of their overall health conditions with the use of boswellic acid ${ }^{(42)}$. The overall relief of some symptoms attributed to boswellic acid is partially explained by the fact that this substance is composed of lipophilic molecules capable of transposing the hematoencephalic barrier which may inhibit topoisomerase I and II, resulting in antiproliferative effects which have been observed in such study among patients with brain tumors ${ }^{(42)}$.

The resin of Boswellia species ('incense', 'olibanum') is used as an incense in religious and cultural ceremonies since ancient times. Its medicinal properties are also broadly known in treating inflammatory diseases, including cancer. Despite its historical, religious, cultural, and medicinal importance, the effects and mechanisms modulated by Boswellia serrata have not yet been fully clarified and deserve thus further studies for its clinical recommendation ${ }^{(69)}$. One approach for cultivation, conservation, and preservation of important vegetal species through plant molecular biology, techniques for cultivating vegetal tissue, extensive and intensive research on the rationality and methodology of ayurvedic practices, isolation of active constituents and their development for new therapeutics, standardization, and validation of known phytotherapeutics, and other related aspects must be continuously focused ${ }^{(68-70)}$.

\section{USE OF CANnABIS SATIVA}

With regards to the use of Cannabis sativa (marijuana extract), the study included in this review has shown positive effects reported by children and parents in $80 \%$ of the cases regarding nausea and vomit, sleep disorders, pain, appetite, and mood, improving thus patient quality of life. However, $14 \%$ of patients who smoked the extract reported throat burning, anxiety attacks, and stomach pain ${ }^{(45)}$. Although marijuana has no absolute contraindications, certain concerns must be considered before it is used, such as family history and dosage, since it can cause addiction; the legal issues in each country must also be observed ${ }^{(45)}$.

Although the medicinal use of Cannabis by oncology patients is mentioned in diverse international scientific publications $^{(71)}$, there are still obstacles and resistance in Brazil due to the culture itself and the law number 11.343, dated August 23, 2006 ${ }^{(72)}$ which criminalizes the use of Cannabis and other substances. Currently, patients who need cannabinoids for treatment or therapeutic well-being face state bureaucracy and the path of judicialization of health ${ }^{(71)}$. Recommendation of this therapy in Brazil is thus faced with major dilemmas.

A study conducted in Minnesota, United States of America ${ }^{(73)}$, pointed that over $90 \%$ of pediatric oncologists showed desire to help children have access to medicinal Cannabis. In this study, $83 \%$ of the interviewed health professionals supported the use of medicinal Cannabis in cancer patients with poorly controlled symptoms ${ }^{(73)}$.

Our systematic review has some limitations. A significant heterogeneity among the included studies was noticed, specially concerning the different $\mathrm{CT}$ and employed protocols, which precluded data meta-analysis, as well as a broader comparison and synthesis of the data. Another limitation is the fact that different interventions are being evaluated in different tumor types, making studies heterogeneous and precluding quantitative analysis. Also, this review does not evaluate the risk of bias among studies. The absence of a control group and the short time of follow-up may have jeopardized the measurement of some study outcomes. For such, new clinical trials are suggested to be conducted, with a longer follow-up period, to verify whether the effects of complementary therapies on the management of cancer symptom clusters in these patients hold for medium and long terms. Therefore, new investigations must be conducted, especially well-designed controlled randomized clinical trials with representative population samples and low risk of bias. The small number of studies retrieved from the databases is partially justified by the difficulties that researchers face worldwide regarding ethical issues, which involve sampling and recruitment of children and adolescent patients with 
cancer undergoing palliative care, and hence, such findings must be valued. Further systematic reviews must observe the pinpointed frailties and develop a more comprehensive search strategy, enabling the retrieval of a higher number of studies. However, this review is considered to present clinical significance for the management of symptom clusters in pediatric cancer patients undergoing palliative care; its results are useful for health professionals providing care to this population.

\section{CONCLUSION}

The synthesized and analyzed evidence point out that the use of therapeutic massage and Reiki might be effective and promising for managing cancer symptom clusters, especially for the cluster pain-anxiety-worry-dyspnea in children and adolescents with cancer undergoing palliative care. Studies evaluating the use of boswellic acid and marijuana, although showing some positive effects, are so far insufficient to precisely demonstrate the effect of such therapies on the management of cancer symptom clusters, mainly because they have shown no statistically significant differences and led to important adverse effects. Thus, further studies are necessary to clarify these findings.

This review's results may subsidize reflections of health professionals, especially pediatric nurses and oncologists, on the use of complementary therapies in addition to conventional treatment in palliative care in pediatric and adolescent oncology, seeking to contribute to their use based on evidence and demystifying these practices while, more importantly, providing a better quality of life to such a specific population.

\section{RESUMO}

Objetivo: Avaliar a efetividade de terapias complementares no manejo dos clusters de sintomas em crianças e adolescentes com câncer em cuidados paliativos. Método: Revisão sistemática guiada pelo Preferred Reporting Items for Systematic Reviews and Meta-Analyses, com acesso às bases de dados MEDLINE, Web of Science, Central Cochrane e PsycINFO. A identificação, seleção, inclusão, extração e avaliação metodológica foram realizadas por dois revisores independentemente. Resultados: Atenderam aos critérios de elegibilidade cinco quase-experimentos. As características heterogêneas dos estudos impossibilitaram a meta-análise. Dois estudos utilizaram a massagem terapêutica; um, o Reiki; um, ácido boswélico; e um, a Cannabis sativa, sendo que três deles (que usaram massagem terapêutica e Reiki) apresentaram resultados estatisticamente significantes para o manejo do cluster dor-ansiedade-preocupação-dispneia. A maioria dos estudos apresentou risco-de-viés moderado pela ferramenta ROBINS-I. Conclusão: A massagem terapêutica e o Reiki podem ser terapias efetivas para o manejo de clusters de sintomas, especialmente o cluster dor-ansiedade-preocupação-dispneia em crianças e adolescentes com câncer em cuidados paliativos.

\section{DESCRITORES}

Criança; Adolescente; Cuidados Paliativos; Terapias Complementares; Enfermagem Oncológica; Revisão.

\section{RESUMEN}

Objetivo: Evaluar la efectividad de las terapias complementarias para el manejo de los grupos de síntomas en niños y adolescentes con cáncer en cuidados paliativos. Método: Revisión sistemática guiada por Preferred Reporting Items for Systematic Revierws and MetaAnalyses, con acceso a las bases de datos MEDLINE, Web of Science, Central Cochrane y PsycINFO. La identificación, selección, inclusión, extracción y evaluación metodológica fueron realizadas por dos revisores de forma independiente. Resultados: Cinco cuasi-experimentos cumplían los criterios de elegibilidad. Las características heterogéneas de los estudios impidieron el metanálisis. Dos estudios utilizaron la terapia de masaje; uno, el Reiki; uno, el ácido boswélico; y uno, la Cannabis sativa; tres de ellos (los que utilizaron la terapia de masaje y el Reiki) mostraron resultados estadísticamente significativos para el tratamiento del grupo dolor-ansiedad-preocupación-disnea. La mayoría de los estudios mostraron un riesgo de sesgo moderado según la herramienta ROBINS-I. Conclusión: La terapia de masaje y el Reiki pueden ser terapias efectivas para el manejo de los grupos de síntomas, especialmente el grupo dolor-ansiedad-preocupacióndisnea en niños y adolescentes con cáncer en cuidados paliativos.

\section{DESCRIPTORES}

Niño; Adolescente; Cuidados Paliativos; Terapias Complementarias; Enfermería Oncológica; Revision.

\section{REFERENCES}

1. Siegel RL, Miller KD, Jemal A. Cancer statistics, 2020. CA Cancer J Clin. 2020;69(1):7-34. doi: 10.3322/caac.21590

2. Force LM, Abdollahpour L, Advani SM, Agius D, Ahmadian E, Alahdab F, et al. The global burden of childhood and adolescent cancer in 2017: an analysis of the Global Burden of Disease Study 2017. Lancet Oncol. 2019;20(9):1211-25. doi: 10.1016/S1470-2045(19)30339-0

3. Bhakta N, Force LM, Allemani C, Atun R, Bray F, Coleman M, et al. Childhood cancer burden: a review of global estimates. Lancet Oncol. 2019;20:e42-53. doi: 10.1016/S1470-2045(18)30761-7

4. Childhood Cancer International. Act now! International childhood cancer day [Internet]. Amsterdam: CCl; [2018]. [cited 2020 Apr 20]. Available from: http://www.internationalchildhoodcancerday.org/ Act-Now.html

5. Instituto Nacional de Câncer José Alencar Gomes da Silva. Estimativa 2020: incidência de câncer no Brasil [Internet]. Rio de Janeiro: INCA; 2019 [citado 2020 abr. 20]. Disponível em: https://www.inca.gov.br/sites/ufu.sti.inca.local/files/media/document/estimativa-2020incidencia-de-cancer-no-brasil.pdf

6. Snaman JM, Kaye EC, Baker JN, Wolfe J. Pediatric palliative oncology: the state of the science and art of caring for children with cancer. Curr Opin Pediatr. 2018;30(1):40-8. doi: 10.1097/MOP.0000000000000573

7. Cheng BT, Rost M, De Clercq E, Arnold L, Elger BS, Wangmo T. Palliative care initiation in pediatric oncology patients: A systematic review. Cancer Med. 2019;8(1):3-12. doi: 10.1002/cam4.1907

8. Nóia TC, Sant'Ana RSE, Santos ADSD, Oliveira SC, Bastos Veras SMC, Lopes-Júnior LC. Coping with the diagnosis and hospitalization of a child with childhood cancer. Invest Educ Enferm. 2015;33(3):465-72. doi: 10.17533/udea.iee.v33n3a10 
9. World Health Organization. National Cancer Control Programmes: polices and managerial guidelines [Internet]. Geneva: WHO; 2002 [cited 2020 Apr 24]. Available from: https://www.who.int/cancer/media/en/408.pdf

10. Friedel M, Aujoulat I, Dubois AC, Degryse JM. Instruments to measure outcomes in pediatric palliative care: a systematic review. Pediatrics. 2019;143(1):e20182379. doi: 10.1542/peds.2018-2379

11. Connor SR, Downing J, Marston J. Estimating the global need for palliative care for children: a cross-sectional analysis. J Pain Symptom Manage. 2017; 53(2):171-7. doi: 10.1016/j.jpainsymman.2016.08.020

12. Rodgers C, Hooke MC, Ward J, Linder LA. Symptom clusters in children and adolescents with cancer. Semin Oncol Nurs. 2016;32(4):394404. doi: 10.1016/j.soncn.2016.08.005

13. Lopes-Júnior LC, Pereira-da-Silva G, Nascimento L, Lima RAG. Cuidados de enfermagem à criança e ao adolescente com câncer e à sua família. In: Gaiva MAM, Ribeiro CA, Rodrigues EC, organizadoras. PROENF Programa de Atualização em Enfermagem: saúde da criança e do adolescente. Porto Alegre: Artmed Panamericana; 2015. p. 87-154.

14. Lopes-Júnior LC, Bomfim EO, Nascimento LC, Pereira-da-Silva G, Lima RA. G. Theory of unpleasant symptoms: support for the management of symptoms in children and adolescents with cancer. Rev Gaucha Enferm. 2015;36(3):109-12. doi: 10.1590/1983- 1447.2015.03.51465

15. Kim HJ, Barsevick AM, Fang CY, Miaskowski C. Common biological pathways underlying the psychoneurological symptom cluster in cancer patients. Cancer Nurs. 2012;35(6):E1-E20. doi:10.1097/NCC.0b013e318233a811

16. Lopes-Júnior LC, Olson K, de Omena Bomfim E, Pereira-da-Silva G, Nascimento LC, et al. Translational research and symptom management in oncology nursing. Br J Nurs. 2016;25(10):S12,S14,S16 passim doi: 10.12968/bjon.2016.25.10.S12

17. Silva MC, Lopes-Júnior LC, Nascimento LC, Lima RA. Fatigue in children and adolescents with cancer from the perspective of health professionals. Rev Latino Am Enfermagem. 2016; 24:e2784. doi: 10.1590/1518-8345.1159.2784

18. Lopes-Júnior LC, Lima RAG. Cancer care and interdisciplinary practice. Cad Saúde Pública. 2019;35(1):e00193218. doi: 10.1590/0102$311 \times 00193218$

19. Von Ah D, Brown CG, Brown SJ, Bryant AL, Davies M, Dodd M, et al. Research agenda of the Oncology Nursing Society: 20192022. Oncol Nurs Forum. 2019;46(6):654-69. doi: 10.1188/19.ONF.654-669

20. Arikan F, Uçar M, Kondak Y, Tekeli A, Kartöz F, Özcan K, et al. Reasons for complementary therapy use by cancer patients, information sources and communication with health professionals. Complement Ther Med. 2019;44:157-61. doi: 10.1016/j.ctim.2019.03.017

21. Freire MEM, Costa SFG, Lima RAG, Sawada NO. Health-related quality of life of patients with cancer in palliative care. Texto Contexto Enferm. 2018;27(2):e5420016. doi: 10.1590/0104-070720180005420016

22. Baviera AF, Olson K, Paula JM, Toneti BF, Sawada NO. Acupuncture in adults with chemotherapy-induced peripheral neuropathy: a systematic review. Rev Latino Am Enfermagem. 2019;27:e3126. doi: 10.1590/1518-8345.2959.3126

23. National Centre for Complementary and Alternative Medicine. Complementary, alternative, or integrative health: what's in a name? [Internet]. Washington: NIH; 2019 [cited 2020 Mar 20]. Available from: http://nccam.nih.gov/health/whatiscam

24. Abrahão CA, Bomfim E, Lopes-Junior LC, Pereira-da-Silva G. Complementary therapies as a strategy to reduce stress and stimulate the immunity of women with breast cancer. J Evid Based Integr Med. 2019;27(24):1-7. doi: 10.1177/2515690X19834169

25. Lopes-Júnior LC, Bomfim EO, Nascimento LC, Nunes MDR, Pereira-da-silva G, Lima RAG. Non-pharmacological interventions to manage fatigue and psychological stress in children and adolescents with cancer: an integrative review. Eur J Cancer Care (Engl). 2016;25(6):92135. doi: 10.1111/ecc.12381

26. Lopes-Júnior LC, Pereira-da-Silva G, Silveira DSC, Veronez LC, Santos JC, Alonso JB, et al. The effect of clown intervention on self-report and biomarker measures of stress and fatigue in pediatric osteosarcoma inpatients: a pilot study. Integr Cancer Ther. 2018;17(3):928-40. doi: $10.1177 / 1534735418781725$

27. Lopes-Júnior LC, Silveira DSC, Olson K, Bomfim EO, Veronez LC, Santos JC, et al. Clown intervention on psychological stress and fatigue in pediatric patients with cancer undergoing chemotherapy. Cancer Nurs. 2020;43(4):290-9. doi: 10.1097/NCC.0000000000000690

28. Nunes MDR, Jacob E, Bomfim EO, Lopes-Júnior CL, Lima RAG, Floria-Santos M, et al. Fatigue and health related quality of life in children and adolescents with cancer. Eur J Oncol Nurs. 2017;29:39-46. doi: 10.1016/j.ejon.2017.05.001

29. Nunes MDR, Bomfim E, Olson K, Lopes-Júnior LC, Silva-Rodrigues FM, Lima RAG, et al. Interventions minimizing fatigue in children/ adolescents with cancer: an integrative review. J Child Health Care. 2018;22(2):186-204. doi: 10.1177/1367493517752498

30. Xavier WS, Pacheco STA, Silva LF, Nascimento LC, Lopes-Júnior LC, Araújo BBM, et al. Nonpharmacological interventions in the improvement of quality of life in children and adolescent cancer patients. Acta Paul Enferm. 2020;33:e-APE-20190022. doi: 10.37689/ acta-ape/2020ar0022

31. Moher D, Liberati A, Tetzlaff J, Altman DG, PRISMA Group. Preferred reporting items for systematic reviews and meta-analyses: the PRISMA statement. PLoS Med. 2009;6(7):e1000097. doi: 10.1371/journal.pmed.1000097

32. Methley AM, Campbell S, Chew-Graham C, McNally R, Cheraghi-Sohi S. PICO, PICOS and SPIDER. A comparison study of specificity and sensitivity in three search tools for qualitative systematic reviews. BMC Health Serv Res. 2014;14:579. doi:10.1371/journal.pmed.1000097

33. Lefebvre C, Manheimer E, Glanville J. Searching for studies. In: Higgins JPT, Greene S, editors. Cochrane Handbook for Systematic Reviews of Interventions, Version 5.0. London: The Cochrane Collaboration; 2008.

34. Ouzzani M, Hammady H, Fedorowicz Z, Elmagarmid A. Rayyan-a web and mobile app for systematic reviews. Syst Rev. 2016;5(1):210. doi: 10.1186/s13643-016-0384-4

35. Carlos L, Lopes-Júnior, Cruz LA, Leopoldo VC, Campos FR, Almeida AM, Silveira RC. Effectiveness of traditional Chinese acupuncture versus sham acupuncture: a systematic review. Rev Latino Am Enfermagem. 2016;24:e2762. doi: 10.1590/1518-8345.0647.2762 
36. Gonçalves CA, Lopes-Júnior LC, Nampo FK, Zilly A, Mayer PCM, Pereira-da-Silva, G. Safety, efficacy and immunogenicity of therapeutic vaccines in the treatment of patients with high-grade cervical intraepithelial neoplasia associated with human papillomavirus: a systematic review protocol. BMJ Open. 2019;9(7):e026975. doi: 10.1136/ bmjopen-2018-026975

37. Lopes-Júnior LC, Lima RAG, Olson K, Bomfim E, Neves ET, Silveira DSC, et al. Systematic review protocol examining the effectiveness of hospital clowns for symptom cluster management in pediatrics. BMJ Open. 2019;9(1):e026524. doi: 10.1136/ bmjopen-2018-026524

38. Lopes-Júnior LC, Rosa MADRP, Lima RAG. Psychological and psychiatric outcomes following PICU admission: a systematic review of cohort studies. Pediatr Crit Care Med. 2018;19(1):e58-e67. doi: 10.1097/PCC.0000000000001390

39. Lopes-Júnior LC, Rosa GS, Pessanha RM, Schuab SIPC, Nunes KZ, Amorim MHC. Efficacy of the complementary therapies in the management of cancer pain in palliative care: A systematic review. Rev Latino Am Enfermagem. 2020;28:e3377. doi: 10.1590/15188345.4213.3377

40. Melnyk BM, Fineout-Overholt E. Evidence-based practice in nursing \& healthcare: guide to best practice. New York: Lippincott Williams \& Wilkins; 2011

41. Sterne JA, Hernán MA, Reeves BC, Savović J, Berkman ND, Viswanathan M, et al. ROBINS-I: a tool for assessing risk of bias in nonrandomised studies of interventions. BMJ. 2016;355:i4919. doi: 10.1136/bmj.i4919

42. JanBen G, Bode U, Breu H, Dohrn B, Engelbrecht V, Gobel U. Boswellic acids in the palliative therapy of children with progressive or relapsed brain tumors. Klin Padiatr. 2000;212(4):189-95. doi: 10.1055/s-2000-9676

43. Thrane SE, Maurer SH, Ren D, Danford CA, Cohen SM. Reiki Therapy for symptom management in children receiving palliative care: a pilot study. Am J Hosp Palliat Care. 2017;34(4):373-9. doi: 10.1177/1049909116630973

44. Weekly T, Riley B, Wichman C, Tibbits M, Weaver M. Impact of a massage therapy intervention for pediatric palliative care patients and their family caregivers. J Palliat Care. 2019;34(3):164-7. doi: 10.1177/0825859718810727

45. Ofir R, Bar-Sela G, Ben-Arush MW, Postovsky S. Medical marijuana use for pediatric oncology patients: single institution experience. Pediatr Hematol Oncol. 2019;36(5):255-66. doi: 10.1080/08880018.2019.1630537

46. Genik ML, McMurtry MC, Marshall S, Rapoport A, Stinson J. Massage therapy for symptom reduction and improved quality of life in children with cancer in palliative care: a pilot study. Complement Ther Med. 2020;48:102263. doi: 10.1016/j.ctim.2019.102263

47. Wolfe J, Grier HE, Klar N, Levin SB, Ellenbogen JM, Salem-Schatz S, et al. Symptoms and suffering at the end of life in children with cancer. N Engl J Med. 2000;342(5):326-33. doi: 10.1056/NEJM200002033420506

48. Collinge W, MacDonald G, Walton T. Massage in supportive cancer care. Semin Oncol Nurs. 2012;28(1):45-54. doi: 10.1016/j. soncn.2011.11.005

49. Karagozoglu S, Kahve E. Effects of back massage on chemotherapy-related fatigue and anxiety: supportive care and therapeutic touch in cancer nursing. Appl Nurs Res. 2013;26(4):210-217. doi: 10.1016/j.apnr.2013.07.002

50. Field T. Massage therapy research review. Complement Ther Clin Pract. 2014;20(4):224-9. doi: 10.1016/j.ctcp.2014.07.002

51. Moyer CA, Rounds J, Hannum JW. A meta-analysis of massage therapy research. Psychol Bull. 2004;130:3-18. doi: 10.1037/00332909.130.1.3

52. Goldman A, Hewitt M, Collins GS, Childs M, Hain R; United Kingdom Children's Cancer Study Group/Paediatric Oncology Nurses' Forum Palliative Care Working Group. Symptoms in children/young people with progressive malignant disease: United Kingdom Children's Cancer Study Group/Paediatric Oncology Nurses Forum Survey. Pediatrics. 2006;117(6):e1179-86. doi: 10.1542/peds.2005-0683

53. Rodríguez-Mansilla J, González-Sánchez B, Torres-Piles S, Martín JG, Jiménez-Palomares M, Bellino MN. Effects of the application of therapeutic massage in children with cancer: a systematic review. Rev Latino Am Enfermagem 2017;25:e2903. doi: 10.1590/15188345.1774.2903

54. Radossi AL, Taromina K, Marjerrison S. A systematic review of integrative clinical trials for supportive care in pediatric oncology: a report from the International Society of Pediatric Oncology. Support Care Cancer. 2018;26:375-91. doi: 10.1007/s00520-017-3908-0

55. Falkensteiner M, Mantovan F, Müller I, Them C. The use of massage therapy for reducing pain, anxiety, and depression in oncological palliative care patients: a narrative review of the literature. ISRN Nurs. 2011;2011:929868. doi: 10.5402/2011/929868

56. Jane SW, Wilkie DJ, Gallucci BB, Beaton RD, Huang HY. Effects of a full-body massage on pain intensity, anxiety, and physiological relaxation in Taiwanese patients with metastatic bone pain: a pilot study. J Pain Symptom Manage. 2009;37(4):754-63. doi: 10.1016/j. jpainsymman.2008.04.021

57. Beider S, Mahrer N, Gold J. Pediatric massage therapy: an overview for clinicians. Pediatr Clin North Am. 2007;54(6):1025-41. doi: 10.1016/j.pcl.2007.10.001

58. Zucchetti G, Candela F, Bottigelli C, Campione G, Parrinello A, Piu P, et al. The power of reiki: feasibility and efficacy of reducing pain in children with cancer undergoing hematopoietic stem cell transplantation. Pediatr Oncol Nurs. 2019;36(5):361-8. doi:10.1177/1043454219845879

59. McManus DE. Reiki is better than placebo and has broad potential as a complementary health therapy. J Evid Based Complementary Altern Med. 2017;22(4):1051-57. doi: 10.1177/2156587217728644

60. Jacobs SS. Integrative therapy use for management of side effects and toxicities experienced by pediatric oncology patients. Children (Basel). 2014;1(3):424-40. doi: 10.3390/children1030424

61. National Center for Complementary and Integrative Health. Reiki [Internet]. Washington: NIH; 2016 [cited 2020 May 20]. Available from: https://www.nccih.nih.gov/health/reiki 2016

62. Thrane S, Cohen SM. Effect of Reiki therapy on pain and anxiety in adults: an in-depth literature review of randomized trials with effect size calculations. Pain Manag Nurs. 2014;15(4):897-908. doi: 10.1016/j.pmn.2013.07.008 
63. Bukowski EL, Berardi D. Reiki brief report: using Reiki to reduce stress levels in a nine-year-old child. Explore (NY). 2014;10(4):253-255. doi: 10.1016/j.explore.2014.02.007

64. Kundu A, Lin Y, Oron AP, Doorenbos AZ. Reiki therapy for postoperative oral pain in pediatric patients: pilot data from a double-blind, randomized clinical trial. Complement Ther Clin Pract. 2014;20(1):21-5. doi:10.1016/j.ctcp.2013.10.010

65. Kundu A, Dolan-Oves R, Dimmers MA, Towle CB, Doorenbos AZ. Reiki training for caregivers of hospitalized pediatric patients: a pilot program. Complement Ther Clin Pract. 2013;19(1):50-4. doi: 10.1016/j.ctcp.2012.08.001

66. Pardhy RS, Bhattacharryya SC. Beta-Boswellic acid, acetyl-b-bos- wellic acid, acetyl-11-keto-b-boswellic acid-boswellic acid, four pentacyclic tripene acids from the resin of Boswellia serrata Roxb. Indian J Chem. 1978;16B:176-8.

67. Hoernlein RF, Orlikowsky T, Zehrer C, Niethammer D, Sailer ER, Simmet T, et al. Acetyl-11-keto-beta-boswellic acid induces apoptosis in HL-60 and CCRF-CEM cells and inhibits topoisomerase I. J Pharmacol Exp Ther. 1999;288(2):613-9.

68. Ammon HP. Modulation of the immune system by Boswellia serrata extracts and boswellic. Phytomedicine. 2010;17(11):862-7. doi: 10.1016/j.phymed.2010.03.003

69. Siddiqui MZ. Boswellia serrata, a potential antiinflammatory agent: an overview. Indian J Pharm Sci. 2011;73(3):255-61. doi: 10.4103/0250$474 X .93507$

70. Brendler T, Brinckmann JA, Schippmann U. Sustainable supply, a foundation for natural product development: The case of Indian frankincense (Boswellia serrata Roxb. ex Colebr.). J Ethnopharmacol. 2018;225:279-86. doi: 10.1016/j.jep.2018.07.017

71. Gasparotto FB, Gamarra CJ. A Influência do estado e os dilemas da democracia brasileira no uso medicinal da Cannabis. Rev Orbis Latina. 2020;10(2).

72. Brasil. Lei n. 11.343, de 23 de agosto de 2006. Institui o Sistema Nacional de Políticas Públicas sobre Drogas - SISNAD; prescreve medidas para prevenção do uso indevido, atenção e reinserção social de usuários e dependentes de drogas; estabelece normas para repressão à produção não autorizada e ao tráfico ilícito de drogas; define crimes e dá outras providências [Internet]. Brasília; 2006 [citado 2020 maio 22]. Disponível em: http://www.planalto.gov.br/ccivil_03/_ato2004-2006/2006/lei/l11343.htm

73. Zylla D, Steele G, Eklund J, Mettner J, Arneson T. Oncology Clinicians and the Minnesota Medical Cannabis Program: a survey on medical cannabis practice patterns, barriers to enrollment, and educational needs. Cannabis Cannabinoid Res. 2018;3(1):195-202. doi: 10.1089/ can.2018.0029.

Financial support:

Fundação de Amparo à Pesquisa e Inovação do Espírito Santo. Process n. 576/2019. 